\title{
The Influence of the Characteristics of the National Business System in the Disclosure of Gender-Related Corporate Social Responsibility Practices
}

\author{
Marcelle Colares Oliveira ${ }^{1, *}(\mathbb{D})$, Manuel Salgueiro Rodrigues Júnior ${ }^{2}$ (D), \\ Sérgio Henrique de Oliveira Lima ${ }^{3}$ (1) and George Alberto de Freitas ${ }^{1}$ (i) \\ 1 Graduate Program in Administration and Controllership, Federal University of Ceará, \\ Fortaleza 60020-180, Brazil; ggfreitas03@yahoo.com.br \\ 2 Centre for Applied Social Studies (CESA), State University of Ceará, Fortaleza 60714-903, Brazil; \\ msrodriguesjr@gmail.com \\ 3 Centre for Applied Social Sciences (CCSA), Federal University of Cariri, Juazeiro do Norte 63048-080, Brazil; \\ shlima05@gmail.com \\ * Correspondence: marcellecolares@uol.com.br
}

Received: 13 February 2018; Accepted: 26 March 2018; Published: 17 April 2018

check for updates

\begin{abstract}
We analysed the influence of the characteristics of national business systems on the disclosure of gender-related corporate social responsibility practices by 150 companies in Latin America that signed the Declaration of Support for Women's Empowerment Principles. The highest level of disclosure was related to the establishment of high-level corporate leadership for gender equality. Results show that the country's level of "concentration of power" and "individualism", and the "orientation towards femininity" have a negative influence on the disclosure of gender-related practices; in addition, the country's level of "economic development" and the "pressure of unions" exert a positive influence. The results highlight the important role that some national and local institutions play in the women's empowerment, leading companies to report information on adopted practices. The study innovates and contributes by introducing the explanation of gender-related social disclosure with the national business system approach in Latin America.
\end{abstract}

Keywords: corporate social responsibility; disclosure; national business system

\section{Introduction}

The characteristics of the institutional environment influence the decisions and strategies of companies towards corporate social responsibility (CSR), the disclosure of information relating to CSR practices and the perception of corporate legitimacy (Blindheim 2015; Matten and Moon 2008). Nevertheless, this dynamic is still apparently poorly understood (García-Sánchez et al. 2016), which has opened up the opportunity for research on CSR and its various aspects, including the disclosure of information; in particular, that relating to gender issues (Gonçalves et al. 2016; Rodríguez-Domínguez et al. 2010; Celis et al. 2015).

Systems for female oppression in patriarchal organisations may originate in the national business system (NBS) of the country in which the organisation's head office is located. This explanation is supported by (Whitley 2003), which presents the nation state as the main unit of political competition, legitimation, definition and defence of private property rights, as well as the main agent capable of influencing the institutions of the capital and labour markets.

Thus, the characteristics of a country's NBS, which, according to the literature review, encompasses the political, financial, educational and labour, cultural and economic systems, and can be the determinant for institutions to promote or repress gender segregation. Consequently, the influence 
of the NBS may lead to higher or lower disclosure of information on company actions or initiatives aimed at reducing gender inequalities. In spite of the inequality of opportunities for women being a very current theme, it is little studied academically; this is equally true for the actions practiced by companies in order to reduce them and the aspects that can influence them accordingly.

Regarding the disclosure tools of these actions, the Global Reporting Initiative (GRI) and the (International Financing Committee 2009, p. 11) emphasise that sustainability reporting - encompassing indicators of economic, environmental and social performance, including gender-may assist in the promotion of gender equality by giving greater transparency to practices and performance related to the issue of gender in organisations.

Many authors believe that, although it is still poor, the disclosure of corporate social information relating to gender about its practices aimed at reducing inequalities, coupled with public policies and innovative actions to address this problem, may contribute to the effective attainment of improvement in the quality of life of citizens (Grosser and Moon 2005, 2008; Vuontisjarvi 2006; Thompson 2008; Grosser 2009). Nevertheless, the characteristics of the national business system that have a positive and negative influence on the adoption of corporate social responsibility practices aimed at gender equity are little explored, although they may have significant impacts on reducing inequalities related to overcoming the serious issues that involve human rights, citizenship, work, employment, and income (Matten and Moon 2008; Aguilera et al. 2007).

Based on the above, the study aims to analyse the influence of the characteristics of the national business systems on the disclosure of practices of corporate social responsibility related to gender by companies in Latin America. It is important to emphasize that there are few studies in the literature that investigate the actions of CSR specifically geared to reducing inequalities of opportunities for gender: many investigate motivations for the adoption of CSR practices and disclosure in general or environmental practices (Chen and Bouvain 2009; Lattemann et al. 2009; Alon et al. 2010; Cahan et al. 2015), others relate aspects of corporate governance as the composition of the board (size, diversity, etc.) with the adoption and dissemination of the RSC (Fuente et al. 2017; Kirsch 2017; Ben-Amar et al. 2017; Helfaya and Moussa 2017; Kassinis et al. 2016; Hyun et al. 2016; Liao et al. 2015; Setó-Pamies 2015; Amran et al. 2014; Giannarakis et al. 2014; Fernandez-Feijoo et al. 2012; Celis et al. 2015; Kato and Naomi 2016); therefore, this study innovates by investigating the phenomenon of adoption of CSR practices geared towards gender using the NBS as theoretical support in companies of Latin America, which in its turn is little studied in literature.

We analysed the influence of the characteristics of national business systems in the disclosure of gender-related corporate social responsibility practices by 150 companies in Latin America that signed the Declaration of Support for Women's Empowerment Principles. The results were obtained after we tested a linear and a non-linear regression model. The results confirm the influence of some characteristics of national business systems in the disclosure of gender-related information: the pressure of unions has a positive influence; the country's level of concentration of power has a negative influence; the country's level of individualism has a negative influence; the country's level of orientation towards femininity has a negative influence; and the country's level of economic development has a positive influence.

The study is justified by the importance of the subject-of promoting gender equity and empowering women at the local, regional and international levels-and it is hoped that the knowledge of disclosure about gender issues by Latin American companies may bring new ideas that reflect the influence of political, economic, financial, educational and cultural differences in the countries. Therefore, the study intends to contribute theoretically to the insertion of the NBS approach in investigations on social disclosure and practically by the investigation in a set of companies in Latin America using WEP as parameter. 


\section{Theoretical Support and Hypotheses}

A growing number of studies investigate the performance of and social disclosure by companies based on the assumptions of the so-called "new institutionalism", as seen in the studies by Campbell (2007); Matten and Moon (2008); Lattemann et al. (2009); Mahadeo et al. (2011); Jensen and Berg (2012); Wang et al. (2016); and Yin (2017).

The disclosure of information by companies can be an instrument of legitimation in relation to their heterogeneous stakeholders and their respective information needs (Deegan 2002); at the moment, it contributes to reducing the asymmetry of information between them (Bonsón and Bednárová 2015; Lopatta et al. 2016).

Whitley $(1999,2003)$ used the term national business system (NBS) to define the set of historically constructed characteristics that are inherent in each country's political, financial, educational and labour, cultural, and economic systems. Keeping similarities with the new institutionalism, the NBS addresses the influence that these characteristics have on (i) the nature of the company (degree of private control over the economic process, degree of discretion granted by owners to managers, and adaptability to changes); (ii) the processes of market organisation (focussing on free transactions or the establishment of alliances, influence of trade associations, and the role of personal relationships); and (iii) the mechanisms of coordination and control of relations between market actors (Hotho 2014; Matten and Moon 2008; Whitley 1999).

The social and environmental practices of organizations-and, consequently, their disclosure-may be influenced by the NBS of the country in which they operate, leading to a discussion of their characteristics. Inspired in the literature review, some aspects associated to the NBS and each one of its systems and related to the CSR disclosure were chosen and hypotheses were presented and discussed in the following sections.

\subsection{Political System}

Jensen and Berg (2012) argue that the political system has the greatest impact on countries whose government interventions are most pronounced. In these cases, the government becomes a stakeholder of greater relevance, demanding resources from companies. Nevertheless, the political system also needs to be effective in public governance, enabling a strong rule of law and greater enforcement power, i.e., enforceability (Fetscherin et al. 2010; Lattemann et al. 2009).

Another relevant factor affecting the political system is corruption. Approximately six billion people live in countries with higher levels of corruption (Transparency International 2015), which has increased the interest of scholars in the subject. In countries where corruption is very high, companies may not have an incentive to maintain high standards of socially and environmentally responsible behaviour (Lattemann et al. 2009). The context of corruption itself, however, may encourage companies to disseminate social information more widely, in an attempt to anticipate the demand for ethical standards from public and private agents (Mahadeo et al. 2011).

Although the political system is involved in many other aspects and not specifically just with enforcement and corruption, these two have been chosen for the following reasons: the first is considered in the literature as or more important than an extensive set of rules and laws for protecting shareholders (Defond and Hung 2004; Durnev et al. 2004), and the second is also considered very important, making up part of relevant indexes on the legal, political and social systems of the countries (Joseph et al. 2016; Transparency International 2015).

Based on the above discussions, the following research hypotheses are suggested:

H1. The level of perceived corruption in the country positively influences the level of disclosure of CSR information related to the gender issue.

H2. The enforcement power of countries positively influences the level of disclosure of CSR information on the gender issue. 


\subsection{Financial System}

Jensen and Berg (2012) emphasise that the main characteristic of a financial system lies in the ease with which financial resources are obtained by companies. The authors suggest that, in market-based economies, the dispersion of minority shareholders is greater, making them more powerful and, subsequently, puts greater restrictions on the release of financial resources. In bank-based economies, in turn, access to resources depends on only one stakeholder, making access easier.

Thus, the tendency is for there to be greater transparency in market-based economies, in order to mitigate stakeholder resistance to the release of financial resources (Ioannou and Serafeim 2012).

Therefore, the following hypothesis is proposed:

H3. Business financing through the capital market positively influences the disclosure of CSR information on the gender issue.

\subsection{Educational and Labour System}

Ioannou and Serafeim (2012) believe that, when the educational system is flawed, few skilled employees are available in the market. In these circumstances, companies seek to send signals of how positive and beneficial their work environment is in order to recruit and retain the most capable employees. Thus, social performance and its disclosure are high in environments where the education system is fragile and, consequently, the skilled workforce is scarce. Turban and Greening $(1997,2000)$ also indicate that CSR practices make the company more attractive as an employer and can bring competitive advantage in that it attracts more qualified employees.

Whitley (2003) indicates that the relationships between employees and employers tend to present strong differences between countries. Jensen and Berg (2012) argue that a considerable determinant of the labour system is the degree of employee participation in employment-related decisions, and that the density of unions in a country goes along with its social and political progress.

Ioannou and Serafeim (2012) confirm this understanding by pointing out that, in countries where unions are more prominent, companies have better social performance, as unions may push for benefits for employees and promote community involvement.

In order to test the influence of the educational and labour system, the following research hypotheses are proposed:

H4. The quality of the country's educational system negatively influences the level of CSR information related to the gender issue.

H5. Union pressure positively influences the disclosure of CSR information on the gender issue.

\subsection{Cultural System}

According to Whitley (2003), a central tenet of economic sociology is that culture and regulatory institutions help to constitute the nature of economic agents and guide their actions.

The Dutch researcher Hofstede in their intercultural studies analyzed data obtained between 1967 and 1973 through questionnaires answered by employees of IBM in 53 different cultures around the world. By means of these studies, he observed patterns of behavior that would be spread among the people in the process of socialization in a particular culture. In this sense, Hofstede (1983) proposed four cultural dimensions: distancing from power, aversion to uncertainty, individualism (vs. collectivism), and masculinity (vs. femininity). Subsequently, Hofstede (1997) includes long-term (vs. short-term) life orientation and indulgence (vs. restriction) dimensions.

The cultural dimensions proposed by Hofstede (1983) are widely used in CSR research, as seen in the studies of Gray (1988); Ioannou and Serafeim (2012); and García-Sánchez et al. (2016)—along with several others-that use such dimensions to establish correlations with CSR practices. 
Long-term (vs. short-term) life orientation and indulgence (vs. restriction) dimensions were not used in this study due to unavailability of data for all countries involved.

\subsubsection{Distancing Power}

Hofstede (1983) argues that the fundamental question involved in this dimension is the way in which society addresses the fact that the distribution of power between people is unequal. In organisations, distancing from power is measured by the degree of hierarchy or centralisation of authority and autocratic leadership. Hofstede (1997) indicates that distancing from power can be defined as the degree to which the least influential members of a country expect equal distribution of power. In this perspective, in countries with characteristics of decentralisation of power, employees are expected to be valued, being consulted for decision-making and achieving higher remuneration.

Gray (1988) indicates that, in societies with a high concentration of power, there is less transparency and a greater demand for confidentiality. Consequently, the disclosure of social information is impaired. With that, the following hypothesis is presented:

H6. The country's level of concentration of power negatively influences the level of CSR information that is inherent in the gender issue.

\subsubsection{Aversion to Uncertainty}

According to Hofstede (1983), the fundamental question involved in this dimension is the way in which society addresses uncertainty, given that the future is unknown and always will be.

García-Sánchez et al. (2016) point out that societies with the lowest aversion to uncertainty are more open to change and have more flexible guidelines. Thus, in these societies, stakeholders have higher expectations regarding CSR practices compared to countries with greater aversion to uncertainty, in which CSR practices are predominantly encouraged through legislation, requiring companies to behave in a standardised way. Therefore, in countries with a lower aversion to uncertainty, companies increase their transparency in order to inform interest groups about their behaviour.

Gray (1988) corroborates this view and, similar to his understanding of the cultural dimension of power, believes that societies with greater aversion to uncertainty have less transparency and a greater demand for confidentiality, with the subsequent loss of information on social policies. Therefore, the following hypothesis is proposed:

H7. The country's level of aversion to uncertainty negatively influences the disclosure of CSR information on the gender issue.

\subsubsection{Individualism vs. Collectivism}

Hofstede $(1983,1997)$ states that the core aspect addressed in this dimension is the relationship between the members of society. In individualistic societies, each person thinks of their own interests to the detriment of those of others. In opposition, in collectivism, one seeks to belong to a group and maintain a harmonious relationship with its members. Collectivist societies are called high context because they establish networks of personal and professional relationships. People form cohesive groups, and it is very important to the harmony between them that resultant relationships are supported by indirect actions and communications; people speak and write profusely. The opposite occurs in individualistic societies, known as low context, in which the communication is direct and very objective.

Gray (1988) used the cultural dimensions of Hofstede (1983) to explain through them how the differences between the countries influenced differences in the characteristics of measuring and disclosing accounting systems.

García-Sánchez et al. (2016) conclude that collectivist societies have higher levels of disclosure of information relating to the CSR due to their being formed by individuals who feel part of a group, 
having strong links with the company, confirming the hypothesis of the study: a higher level of collectivism of the country generates a greater disclosure of information of CSR.

Similarly, Jensen and Berg (2012) observed that companies located in individualistic environments are not open to disclosure of information. Therefore, it is possible to propose the following hypothesis:

H8. The level of individualism in the country negatively influences the disclosure of CSR information inherent in the gender issue.

\subsubsection{Masculinity vs. Femininity}

Countries with masculinity characteristics are more focussed on competitiveness and personal material success. In contrast, in countries with a predominance of female characteristics, concern for quality of life and environment is very strong (Hofstede 1983). In addition, feminine cultures are more geared to cooperation and solidarity, and "sympathy for the unfortunate" prevails (Hofstede 1983, p. 63), which means that minorities are very focused upon in these cultures.

Ringov and Zollo (2007) studied the influence of the four cultural dimensions of Hofstede on the CSR on firms on North America, Europe and Asia and found that masculinity has a significant negative effect on corporate social and environmental performance. Scholtens and Dam (2007) made observations relating to the effect of the four dimensions of Hofstede that individualism and uncertainty avoidance are positively associated with ethical corporative policies, whereas masculinity and power distance are negatively related to these policies. As well as these studies cited, others also associate aspects of corporate social responsibility with the dimensions of Hofstede.

According to García-Sánchez et al. (2016), firms located in a culture characterized by being a feminine country are more prone to disclose social information than otherwise. García-Sánchez et al. (2016) have identified, in a sample composed of 1598 international companies from 20 countries for the years 2004-2010, that a society with higher cultural values for orientation towards women is more sensitive to the publication of corporate social responsibility reports.

Therefore, the following hypothesis can be formulated:

H9. The country's level of orientation towards femininity positively influences the disclosure of CSR information related to the gender issue.

\subsection{Economic System}

Belal (2000) reveals, based on research conducted with 30 companies in Bangladesh, that, in general, the quantity and quality of disclosures from companies in developing countries appear to be inadequate and poor compared to environmental disclosures in developed countries.

Neumayer and Perkins (2004) point to several studies that corroborate the results of Belal (2000), justifying the situation by the high costs of promoting environmental practices, mainly related to disclosure. According to Jensen and Berg (2012), in developed countries, there is a tendency to show more sophisticated social information.

One of the most common indices for measuring a nation's economic development is the per capita gross domestic product (GDP). Baughn et al. (2007) tested this parameter and identified a positive relationship between GDP per capita and CSR. Fetscherin et al. (2010) make the same indication in a later study.

Another factor that can affect a country's institutional variables is economic freedom. Campbell (2007) argues that firms operating in low-profit or high-competition markets may have fewer incentives to engage in socially responsible practices as a result of a greater scarcity of resources for this purpose. On the other hand, in scenarios with little or no competition, there would be no market incentives for performance and corporate social and environmental disclosure. 
Taking per capita GDP and the degree of economic freedom as proxies for economic development, Jensen and Berg (2012) have identified that companies operating in more developed countries have a higher level of disclosure of CSR information.

Based on the above discussions, the following hypotheses are proposed:

H10. The level of economic development in the country positively influences the disclosure of gender-related CSR information.

H11. The level of economic freedom in the country positively influences the disclosure of gender-related CSR information.

\section{Methodology}

The quantitative research was based on documentary analysis to identify the disclosure of information about practices aimed at gender equity in companies operating in Latin America. We decided to study the companies in the region whose Chief Executive Officer (CEO) signed the Women's Empowerment Principles (WEP) Support Statement. Thus, the studied population consisted of 150 companies, whose countries and respective quantities are presented below: Argentina, 15; Brazil, 99; Chile, 6; Colombia, 7; Costa Rica, 2; Ecuador, 4; Mexico, 10; Panama, 1; Peru, 5; and Venezuela, 1. We did not consider the only Bolivian company that adhered to WEP because there were no data available from this country's cultural system. This exclusion was made due to the lack of data in the explanatory variables.

The disclosure of CSR practices related to gender was obtained on the websites of the firms studied or from organisations such as stock exchanges or securities commissions, in documents such as sustainability reports, annual reports, integrated reports, reference forms, etc. The data collected refer to the fiscal year which ended in 2015 (at the completion of the study, the data for 2016 were still being compiled by some of the companies).

The documents were analysed to identify the gender information disclosed by the companies, as explained in Table 1, in the following section. Subsequently, the information was quantified to measure the level of disclosure of each company and, in the aggregate data, of each country. Statistical tests were carried out to verify the influence of the characteristics of the national business systems on the disclosure of social information regarding the gender issue by the companies in the countries studied.

Table 1. Alignment of Women's Empowerment Principles (WEP) with the corporate social responsibility (CSR) indicators of the Global Reporting Initiative (GRI) guidelines.

\begin{tabular}{|c|c|c|}
\hline WEP & $\begin{array}{l}\text { G4 Guideline Indicator } \\
\text { (UN Guideline-2014) }\end{array}$ & Gender Information to be Disclosed \\
\hline \multirow[b]{2}{*}{ P1 } & G4-38 & Composition of the highest governance body and its committees by gender. \\
\hline & G4-40 & Criteria adopted to select and appoint members of the highest governance body. \\
\hline \multirow{6}{*}{ P2 } & G4-LA1 & $\begin{array}{l}\text { Total number and rates of new hiring of employees and employee turnover by } \\
\text { age group, gender, and region. }\end{array}$ \\
\hline & G4-LA12 & $\begin{array}{l}\text { Composition of groups responsible for governance and discrimination of } \\
\text { employees by functional category, according to gender. }\end{array}$ \\
\hline & G4-LA13 & $\begin{array}{l}\text { Mathematical reason for salary and remuneration between women and men, } \\
\text { broken down by functional category and relevant operating units. }\end{array}$ \\
\hline & G4-EC5 & Variation of the proportion of the lowest wage, broken down by gender. \\
\hline & G4-LA3 & $\begin{array}{l}\text { Rates of return to work and retention after maternity/paternity leave, broken } \\
\text { down by gender }\end{array}$ \\
\hline & G4-HR3 & Total number of cases of discrimination and corrective measures taken. \\
\hline \multirow[b]{2}{*}{ P3 } & G4-HR3 & Total number of cases of discrimination and corrective measures taken. \\
\hline & G4-LA6 & $\begin{array}{l}\text { Types and rates of injuries, occupational diseases, days missed, absenteeism and } \\
\text { number of work-related deaths, broken down by region and gender. }\end{array}$ \\
\hline
\end{tabular}


Table 1. Cont.

\begin{tabular}{ccc}
\hline WEP & $\begin{array}{l}\text { G4 Guideline Indicator } \\
\text { (UN Guideline-2014) }\end{array}$ & Gender Information to be Disclosed \\
\hline P4 & G4-LA9 & $\begin{array}{l}\text { Average number of hours of training per year per employee, broken down by } \\
\text { gender and functional category. }\end{array}$ \\
\cline { 2 - 3 } P5 & G4-LA11 & $\begin{array}{l}\text { Percentage of employees who regularly receive performance and career } \\
\text { development assessments, broken down by gender and functional category. }\end{array}$ \\
\hline P6 & G4-SO1 & $\begin{array}{l}\text { Describe policies and practices that promote inclusion when selecting suppliers. } \\
\text { ercentage of operations with programmes implemented for local community } \\
\text { engagement, impact assessment, and local development. }\end{array}$ \\
\hline
\end{tabular}

\subsection{Data Collection Instrument}

With the aim of making the disclosure of gender-related corporate information more objective, the United Nations, through UN Women and the aUN Global Compact, has developed a specific guideline based on the Women's Empowerment Principles (WEP):

- $\quad$ Principle 1: Establish high-level corporate leadership for gender equality.

- Principle 2: Treat all men and women fairly at work-respect and support human rights and non-discrimination.

- $\quad$ Principle 3: Ensure the health, safety and well-being of all women and men workers.

- $\quad$ Principle 4: Promote education, training and professional development for women.

- Principle 5: Implement business development, supply chain and marketing practices that empower women.

- $\quad$ Principle 6: Promote equality through community initiatives and advocacy.

- $\quad$ Principle 7: Measure and publicly report progress to achieve gender equality.

For the development of the data collection instrument, the WEP of UN Women was taken as a basis, as these principles are aimed at the business environment and seek to guide the process of strengthening women in the work environment and the community. In the UN guideline, which is specific for disseminating progress on gender, it is possible to perceive the alignment of the principles to the guidelines of the Global Reporting Initiative (GRI). The gender issues suggested by the WEP guide in six principles are addressed in different GRI indicators. Table 1 illustrates the arrangement proposed by the UN. Principle 7 deals with the disclosure of practices that ensure female empowerment and, consequently, has a relationship with all other principles, because it is possible to identify the routines of companies regarding gender.

A data collection instrument was developed using an MS Excel ${ }^{\circledR}$ worksheet in which the gender information was disclosed by the companies, as specified in the last column of Table 1 . We identified a total of 14 disclosure items distributed in 13 GRI indicators, corresponding to six of the WEPs. For each indicator, we used keywords to facilitate and standardise data collection. We also consolidated data by country.

\subsection{Dependent Variable: Level of Disclosure of Gender-Related Information}

Based on the documentary analysis carried out and its transformation into numerical language, it was possible to quantify the disclosure of the gender information of each indicator ( 0 for "nothing disclosed", 1 for "partially disclosed" and 2 for "fully disclosed"). Thus, the score of each company may vary, in discrete terms, between 0 and 28 points, based on the completeness of the information disclosed. Despite adopting different proxies, a similar quantification methodology was used in some studies on disclosure, such as those of Bonsón and Bednárová (2015) and Lopatta et al. (2016). 


\subsection{Independent Variables}

According to the hypotheses proposed in the literature review, the independent variables defined for the research were perceived corruption (H1); enforcement power (H2); financing by the capital market (H3); quality of the education system (H4); influence of trade unions (H5); power distance (H6); aversion to uncertainty (H7); individualism vs. collectivism (H8); masculinity vs. femininity (H9); economic development (H10); and economic freedom (H11). The aim is to verify if these variables influence the disclosure of CSR practices related to gender of the population of WEP signatory companies in the countries studied.

Table 2 presents a summary of all the research variables, their corresponding hypotheses, the form of operationalization, and the data sources (empirical and theoretical).

Table 2. Description of the studied variables.

\begin{tabular}{|c|c|c|c|c|c|}
\hline System & $\begin{array}{l}\text { Independent } \\
\text { Variables }\end{array}$ & Indicator & Source & Operationalization & Previous Studies \\
\hline \multirow[b]{2}{*}{ Political } & H1: CORRUP & $\begin{array}{l}\text { Perceived } \\
\text { Corruption Index }\end{array}$ & $\begin{array}{l}\text { Transparency } \\
\text { International (2015) }\end{array}$ & $\begin{array}{l}\text { Score obtained by country, } \\
\text { ranging from } 0 \text { (highly } \\
\text { corrupt) to } 100 \text { (no corruption) }\end{array}$ & $\begin{array}{l}\text { (Lattemann et al. 2009; } \\
\text { Mahadeo et al. 2011). }\end{array}$ \\
\hline & H2: ENFORC & $\begin{array}{l}\text { Rule of Law: } \\
\text { Estimate }\end{array}$ & $\begin{array}{l}\text { The World Bank } \\
\text { (2016) }\end{array}$ & $\begin{array}{l}\text { Score obtained by country, } \\
\text { ranging from }-2.5 \text { (lower } \\
\text { presence of the rule of law) to } \\
+2.5 \text { (greater presence of the } \\
\text { rule of law) }\end{array}$ & $\begin{array}{l}\text { (Fetscherin et al. 2010; } \\
\text { Lattemann et al. 2009). }\end{array}$ \\
\hline Financial & H3: FINANC & $\begin{array}{l}\text { Financing through } \\
\text { local equity market }\end{array}$ & $\begin{array}{l}\text { World Economic } \\
\text { Forum (World } \\
\text { Economic Forum } \\
\text { 2016) }\end{array}$ & $\begin{array}{l}\text { Score obtained by country, } \\
\text { from } 1 \text { (extremely difficult) to } \\
7 \text { (extremely easy) }\end{array}$ & $\begin{array}{l}\text { (Jensen and Berg 2012; } \\
\text { Ioannou and Serafeim } \\
\text { 2012). }\end{array}$ \\
\hline $\begin{array}{l}\text { Educational } \\
\text { and Labour }\end{array}$ & H4: EDUC & $\begin{array}{l}\text { Quality of the } \\
\text { education }\end{array}$ & $\begin{array}{l}\text { World Economic } \\
\text { Forum (2016) }\end{array}$ & $\begin{array}{l}\text { Score obtained by country, } \\
\text { ranging from } 1 \text { (not satisfying } \\
\text { at all) to } 7 \text { (highly satisfactory) }\end{array}$ & $\begin{array}{l}\text { (Ioannou and Serafeim } \\
\text { 2012; Turban and } \\
\text { Greening 1997, 2000). }\end{array}$ \\
\hline \multirow{2}{*}{ Cultural } & H6: DPOWER & $\begin{array}{l}\text { Cultural dimension } \\
\text { of power } \\
\text { distance-Score } \\
\text { obtained by country }\end{array}$ & (Hofstede 2016) & $\begin{array}{l}\text { Score obtained by country, } \\
\text { ranging from } 0 \text { (no power } \\
\text { distance) to } 100 \text { (maximum } \\
\text { power distance) }\end{array}$ & $\begin{array}{l}\text { (Gray 1988; Hofstede } \\
\text { 1997; García-Sánchez } \\
\text { et al. 2016). }\end{array}$ \\
\hline & H7: AVUNCER & $\begin{array}{l}\text { Cultural dimension } \\
\text { of aversion to } \\
\text { uncertainty }\end{array}$ & (Hofstede 2016) & $\begin{array}{l}\text { Score obtained by country, } \\
\text { varying from } 0 \text { (no aversion to } \\
\text { uncertainty) and } 100 \\
\text { (maximum aversion to } \\
\text { uncertainty) }\end{array}$ & $\begin{array}{l}\text { (Gray 1988; } \\
\text { García-Sánchez et al. } \\
\text { 2016). }\end{array}$ \\
\hline \multirow[b]{2}{*}{ Economic } & H10: PCGDP & $\begin{array}{l}\text { Per capita Gross } \\
\text { Domestic Product } \\
\text { (GDP) }\end{array}$ & $\begin{array}{l}\text { (International } \\
\text { Monetary Fund 2016) }\end{array}$ & Score obtained by country & $\begin{array}{l}\text { (Baughn et al. 2007; } \\
\text { Lattemann et al. 2009; } \\
\text { Jensen and Berg 2012). }\end{array}$ \\
\hline & H11: IEF & $\begin{array}{l}\text { Index of Economic } \\
\text { Freedom (IEF) }\end{array}$ & $\begin{array}{l}\text { Heritage Foundation } \\
\text { (2016) }\end{array}$ & $\begin{array}{l}\text { Score obtained by country, } \\
\text { ranging from } 0 \text { (no freedom) } \\
\text { to } 100 \text { (higher level of } \\
\text { economic freedom) }\end{array}$ & $\begin{array}{l}\text { (Lattemann et al. 2009; } \\
\text { Jensen and Berg 2012). }\end{array}$ \\
\hline
\end{tabular}

Source: Prepared by the authors. 


\subsection{Empirical Model}

Following the definition of the variables and expected signals for the hypothesis test, the multiple regression model was chosen as the data analysis method, with the following functional form:

$$
\begin{gathered}
\text { DISCLi }=\beta_{0}+\beta_{1}(\text { CORRUPi })+\beta_{2}(\text { ENFORCi })+\beta_{3}(\text { FINANCi })+\beta_{4}(\text { EDUCi })+\beta_{5}(\mathrm{UNIONi})+ \\
\beta_{6}(\text { DPOWERi })+\beta_{7}(\text { AVUNCERi })+\beta_{8}(\text { INDIVIDi })+\beta_{9}(\text { FEMINi })+\beta_{10}(\text { PCGDPi })+\beta_{11}(\text { IEFi })+\varepsilon_{i}
\end{gathered}
$$

Initially, the results were obtained after we tested a linear and a non-linear regression model. The linear regression model was estimated by ordinary least squares (OLS), while the nonlinear model adopted was Poisson's regression. The reason for seeking to estimate the model parameters through Poisson regression lies in the fact that the dependent variable takes on integer, finite, and non-negative values.

According to Wooldridge (2012), although the linear model may not provide the best fit for all variables, it is always interesting to initiate attempts by this model. On the other hand, Poisson regression allows consistent and asymptotically normal estimators to be obtained even though it violates the premise that the dependent variable assumes Poisson distribution. Afterwards, alternatives were tested for specification for OLS and Poisson, considering the particularities and limitations of each model, when applying the Ramsey specification test to the linear model as an alternative analysis of results. The tests were performed with the aid of the Grett ${ }^{\circledR}$ statistical software program.

\section{Analysis of Results}

\subsection{Analysis of the Level of Disclosure}

We show the level of disclosure of social information related to gender among all 150 companies studied in Table 3, consolidating the scores by indicator and by country.

\begin{tabular}{|c|c|c|c|c|c|c|c|c|c|c|c|}
\hline Indicator & ARG $(n=15)$ & $\begin{array}{c}\text { BRA } \\
\text { (99) }\end{array}$ & $\begin{array}{c}\text { CHI } \\
(6)\end{array}$ & $\begin{array}{c}\text { COL } \\
(7)\end{array}$ & $\begin{array}{c}\text { COS } \\
\text { (S) }\end{array}$ & $\begin{array}{c}\text { ECU } \\
(4)\end{array}$ & $\begin{array}{c}\text { MEX } \\
(10)\end{array}$ & $\begin{array}{c}\text { PAN } \\
\text { (1) }\end{array}$ & $\begin{array}{c}\text { PER } \\
(5)\end{array}$ & $\begin{array}{c}\text { VEN } \\
\text { (1) }\end{array}$ & $\begin{array}{l}\text { Total } \\
\text { (150) }\end{array}$ \\
\hline G4-38 & 1.87 & 1.15 & 1.67 & 1.71 & 1.00 & 1.00 & 0.60 & - & 1.20 & 2.00 & 1.23 \\
\hline G4-40 & 0.53 & 0.81 & 1.00 & 1.14 & - & 0.50 & 0.20 & - & 0.80 & - & 0.73 \\
\hline G4-LA1 & 0.87 & 0.37 & 0.33 & 0.57 & 0.50 & 0.75 & 0.20 & - & 0.20 & 1.00 & 0.43 \\
\hline G4-LA12 & 1.53 & 1.03 & 1.83 & 1.86 & 1.00 & 1.25 & 0.50 & - & 1.20 & 2.00 & 1.13 \\
\hline G4-LA13 & 1.07 & 0.57 & 0.33 & 0.57 & - & - & 0.10 & - & 0.40 & - & 0.54 \\
\hline G4-EC5 & 0.67 & 0.45 & - & 0.57 & - & 0.50 & - & - & 0.80 & - & 0.43 \\
\hline G4-LA3 & 0.13 & 0.16 & - & 0.29 & - & - & 0.20 & - & - & - & 0.15 \\
\hline G4-HR3 ${ }^{(1)}$ & 1.07 & 0.48 & 0.33 & 0.57 & 1.00 & 0.75 & 0.40 & - & 1.20 & 2.00 & 0.58 \\
\hline G4-LA6 & 0.40 & 0.26 & 0.33 & 0.29 & - & - & - & - & - & - & 0.24 \\
\hline G4-LA9 & 0.80 & 0.36 & 1.00 & 0.57 & - & 0.50 & 0.20 & - & - & - & 0.41 \\
\hline G4-LA11 & 0.60 & 0.29 & - & 0.57 & - & - & 0.10 & - & - & - & 0.29 \\
\hline G4-DMA & 0.07 & 0.21 & 0.33 & 0.14 & - & - & 0.10 & - & - & - & 0.17 \\
\hline G4-SO1 & 0.47 & 0.56 & 0.67 & 0.43 & 0.50 & 0.25 & 0.20 & - & 0.40 & 1.00 & 0.51 \\
\hline Total & 11.13 & 7.20 & 8.17 & 9.86 & 5.00 & 6.25 & 3.20 & - & 7.40 & 10.00 & 7.41 \\
\hline
\end{tabular}

Table 3. Average of the social disclosure of gender information, by indicator, country, and total for Latin America.

Source: Prepared by the authors. ${ }^{(1)}$ The indicator for the total number of cases of discrimination and corrective measures taken (G4-HR3) has a weight of 2, as it appears in two principles.

For each indicator, the average disclosure of companies in a country can vary between 0 and 2 points. For each country, the sum of these averages for the 14 indicators can reach 28 points. The indicators that obtained the highest level of disclosure were composition of the highest governance body and its committees by gender (G4-38), and composition of the groups responsible for governance and discrimination of employees by functional category, according to gender (G4-LA12). The indicator relating to return to work and retention after maternity/paternity leave, broken down by gender (G4-LA3), was the least publicised. 
Argentina, Colombia, Chile and Venezuela were the countries that presented the highest level of disclosure; however, it should be noted that the latter has only one company that adhered to the WEPs. Table 3 also shows that the Panamanian company and the Mexican companies were the ones with the lowest level of disclosure. The only Panamanian company among the 150 companies studied scored zero on all indicators: that is, we searched data but nothing was reported and its level of disclosure about gender was equal to zero.

The companies obtained, on average, a disclosure level of 7.41 points, which accounts of $26.5 \%$ of the maximum possible level, i.e., 28 points. This level of disclosure can be considered low, as the companies studied have committed themselves to adopting the WEPs, which encompasses disclosure in addition to the adoption of certain practices aimed at empowering women. Additionally, the most publicised practices refer to the composition of the bodies, committees and groups responsible for the governance of these companies, broken down by gender, which does not mean that the results pointed to women's composition, but that companies disclose their composition. Indeed, few of these companies feature women as members of groups responsible for the governance. These results refer to the findings of Kato and Naomi (2016) and Celis et al. (2015) on CSR and women in open government bodies in Japan and Spain, respectively, which highlight the importance of women in these bodies to the achievement of national gender equality objectives.

We observed that Principle 1, related to the establishment of a high-level corporate leadership for gender equality, composed of indicators G4-38 and G4-40, obtained greater disclosure. Principle 5, which is composed of the G4-DMA indicator, related to business development and supply chain and marketing practices that empower women, had the lowest disclosure. This situation is repeated when we observe the numbers by country.

The results of research in these Latin American companies corroborate the findings of Grosser and Moon (2008), who investigated the extension of the external reports of UK companies-with regard to gender equality in the workplace-and found that companies rarely report data segregated by gender. They also coincide with those of Vuontisjarvi (2006), analysing the disclosure of CSR in Finnish companies, in which they noted a lack of information on equality of opportunity, which should go beyond mere segregation by gender structure. Finally, as shown in Adams and Harte (1998), who examined gender disclosure in the annual reports of British companies and found that the position of women in the sectors of companies studied may be partly explained by patriarchal management practices, the results observed in the companies studied in Latin America reinforce the need to investigate national characteristics that influence this disclosure, such as those that will be analysed below.

\subsection{Analysis of Collinearity, Heteroscedasticity and Normality}

In order to investigate possible interference of collinearity in the results of the model, the variance inflation factors (VIF) test was applied. Variables were removed from the model as the test indicated strong or moderate collinearity. In this process, the variables CORRUPT (H1), EDUC (H4) and IEF (H11) were excluded. The VIF of the remaining variables presented values close to ten (10), an acceptable collinearity standard $($ ENFORC $=11.591$, FINANC $=16.669$, UNION $=7.494$, DPOWER $=$ 9.010, AVUNCER $=4.520$, INDIVID = 6.408, FEMIN = 5.171, and PCGDP = 3.918).

For correction of heteroscedasticity, the regression estimation considered the robust standard error, avoiding estimation bias. This correction is necessary, as "all distributions of counting data present heteroskedasticity" (Wooldridge 2012, p. 558). Furthermore, as for normality, "a counting variable cannot have a normal distribution (since the normal distribution is related to continuous variables that can assume all values [ ... ]). Instead, the normal distribution of counting data is the Poisson distribution" (Wooldridge 2012, p. 558).

\subsection{Testing Hypotheses and Discussions}

We show the results generated by the OLS and Poisson regression models in Table 4. 
Table 4. Regression results.

\begin{tabular}{|c|c|c|c|c|c|c|c|c|c|}
\hline & Const. & ENFORC & FINANC & UNION & DPOWER & AVUNCER & INDIVID & FEMIN & PCGDP \\
\hline Hypothesis & & $\mathrm{H} 2$ & H3 & H5 & H6 & $\mathrm{H} 7$ & H8 & H9 & H10 \\
\hline Exp. Signal & & + & - & - & - & - & - & - & + \\
\hline \multicolumn{10}{|c|}{ Linear Regression (OLS) } \\
\hline$\beta_{i}$ & -9.82 & -7.78 & 10.04 & 1.12 & -1.80 & -3.29 & 0.49 & 0.65 & 1.07 \\
\hline $\mathrm{t}$ & -0.53 & -1.58 & 2.34 & 0.42 & -1.20 & -1.16 & 0.37 & 0.45 & 2.13 \\
\hline $\begin{array}{c}p \text {-value } \\
\text { Signal (Sig.) }\end{array}$ & 0.59 & 0.1163 & $\begin{array}{l}0.0207 \\
\left.+{ }^{* *}\right)\end{array}$ & 0.6760 & 0.2328 & 0.2475 & 0.7113 & 0.6515 & $\begin{array}{l}0.035 \\
+(* *)\end{array}$ \\
\hline Test & & $\begin{array}{l}\text { Does not } \\
\text { influence }\end{array}$ & Rejects & $\begin{array}{l}\text { Does not } \\
\text { influence }\end{array}$ & $\begin{array}{l}\text { Does not } \\
\text { influence }\end{array}$ & $\begin{array}{l}\text { Does not } \\
\text { influence }\end{array}$ & $\begin{array}{l}\text { Does not } \\
\text { influence }\end{array}$ & $\begin{array}{l}\text { Does not } \\
\text { influence }\end{array}$ & $\begin{array}{c}\text { Does Not } \\
\text { Reject }\end{array}$ \\
\hline \multicolumn{10}{|c|}{ Non-linear Regression (Poisson) } \\
\hline$\beta_{i}$ & -5.79 & -2.87 & 6.36 & -2.80 & -1.25 & -0.42 & -0.35 & 1.13 & 0.37 \\
\hline Z & -1.36 & -1.97 & 2.38 & -2.33 & -2.67 & -1.40 & -2.51 & 3.13 & 2.34 \\
\hline$p$-value & 0.173 & 0.0481 & 0.0171 & 0.0194 & 0.0075 & 0.1589 & 0.0119 & 0.0017 & 0.0191 \\
\hline Signal (Sig.) & & $-(* *)$ & $+(* *)$ & $-\left({ }^{* *}\right)$ & $-(* * *)$ & & $-(* *)$ & $+(* * *)$ & $+\left({ }^{* *}\right)$ \\
\hline Test & & Rejects & Rejects & $\begin{array}{c}\text { Does Not } \\
\text { Reject }\end{array}$ & $\begin{array}{c}\text { Does Not } \\
\text { Reject }\end{array}$ & $\begin{array}{l}\text { Does not } \\
\text { influence }\end{array}$ & $\begin{array}{c}\text { Does Not } \\
\text { Reject }\end{array}$ & Rejects & $\begin{array}{c}\text { Does Not } \\
\text { Reject }\end{array}$ \\
\hline
\end{tabular}

OLS Adjusted R ${ }^{2}$ : 0.004317; Poisson Adjusted $R^{2}: 0.056135$. ${ }^{* *}$ Significant at $p<0.05$; ${ }^{* * *}$ Significant at $p<0.01$. Source: Research data $(n=150)$.

We quote Wooldridge (2012) to show that OLS may not provide the best fit. This was confirmed for the data set analysed, because the null hypothesis of the Ramsey specification test was rejected at $5 \%$. In the results, only two variables were significant. For these reasons, we will discuss below the results obtained by the Poisson model.

In relation to the political system (hypothesis $\mathrm{H} 2$ ), the results showed a significant, albeit negative, influence on $p<0.05$ on gender disclosure, for which $\mathrm{H} 2$ was rejected. Further regulation does not lead to a higher level of disclosure of gender-related CSR information, as opposed to earlier studies (Lattemann et al. 2009; Fetscherin et al. 2010). This result indicates that companies do not respond in full compliance with the rule of law, disclosing even less gender information as disclosure requirements grow, i.e., companies tend to disclose the minimum required in the regulation.

Disclosure enforcement primarily focusses on mandatory financial information. Nevertheless, in cases where voluntary disclosure-in the case of CSR policies and, in particular, gender equity-impairs the firm's capitalisation, this information may be withheld, as they are unfavourable (Verrecchia 2001). This argument is supported by the low general level of disclosure of CSR practices related to gender by the companies investigated (7.41 general average on a scale up to 28 points). Nevertheless, future research should be carried out to verify empirically why enforcement in countries studied have a negative impact on CSR disclosure. According to Braendle (2014), in emerging countries such as those in the BRICS bloc, adherence to regulations is not hampered by the fragility of the system of legislation for corporate relations, but by the low level of enforcement effectiveness.

Hypothesis H3, relating to the country's financial system, was rejected at $p<0.05$, refuting the positive influence of capital market financing on the disclosure of CSR information related to gender issues. Considering that the gradation of the variable ranges from 1 (extremely difficult or market-based) to 7 (extremely easy or bank-based), the positive relation proposed in $\mathrm{H}_{3}$ was rejected because the regression signal was positive; that is, the higher the value of the variable, the higher the level of disclosure. This result confronts the empirical evidence presented in the study (Jensen and Berg 2012; Ioannou and Serafeim 2012), and indicates that, in the countries studied, there is no demand from stakeholders for transparency and disclosure by companies regarding this information. On the other hand, this result may be associated with the incipient stage of development of the capital markets of the countries studied or even with the government's participation in the financing of companies.

The influence of the working system, hypothesis $\mathrm{H} 5$, was not rejected, reaching a significance level $p<0.05$. According to the theoretical support consulted, the power of unions positively affects the level of disclosure of CSR information in general (Jensen and Berg 2012; Ioannou and Serafeim 2012). The results showed a positive influence exerted by this variable on the specific disclosure of 
gender equity practices in the WEP signatory companies of the countries studied. Considering that the gradation of the variable ranges from 1 (confrontation relationship) to 7 (collaborative relationship), the positive influence proposed in $\mathrm{H} 5$ was confirmed because the regression signal was negative; that is, the lower the value of the variable, or the more pressure exercised by the unions, the greater the level of disclosure.

In relation to the cultural system, we first investigated the negative influence of the concentration of power on the disclosure of information on gender practices, through the test of hypothesis H6. The results confirm H6 at $p<0.01$ and corroborate the findings of (Gray 1988), indicating that, in countries with greater concentration of power, there is less transparency, and the disclosure of social information is impaired.

Also, in the context of the country's cultural system, the influence of the dimension aversion to uncertainty on the level of disclosure of gender CSR (hypothesis H7) — expected to be negative-was analysed. The results, however, showed that the estimator is not statistically significant at $p<0.1$, not representing any influence on the dependent variable. The test of hypothesis $\mathrm{H} 8$, in turn, verified whether the cultural dimension of individualism negatively affects the disclosure of CSR of gender. In line with the findings of Gray (1988) and García-Sánchez et al. (2016), the study confirmed, at a significance level $p<0.05$, that companies operating in countries with a more individualistic-as opposed to more collectivistic — cultural system are less likely to disclose their information, hampering the disclosure of social practices.

The last characteristic of the cultural system was the orientation of the country towards femininity. The results obtained led to the rejection of hypothesis $\mathrm{H} 9$ at $p<0.01$, showing the negative influence that the country's orientation towards femininity, as opposed to masculinity, exerts on the disclosure of CSR information related to gender. This result is opposite to that found in García-Sánchez et al. (2016), i.e., the country's orientation towards masculinity positively influenced the companies studied in increasing the level of disclosure. Thus, the need for future research to verify empirically why the orientation towards femininity in the countries studied negatively influences the disclosure of CSR gender actions is reinforced.

The importance of the economic system for the disclosure of social practices of gender equity was analysed based on the variable of economic development (PCGDP) in hypothesis H10. The results confirmed $\mathrm{H} 10$ and corroborated the previous empirical evidence (Baughn et al. 2007; Lattemann et al. 2009; Jensen and Berg 2012), showing the positive influence exerted by the country's level of economic development on disclosure of gender-related CSR information.

In summary, the work dimension of the NBS showed a positive influence on the observed level of disclosure, highlighting the importance of union pressure and confirming, in the companies studied in Latin America, the results of the Jensen and Berg (2012) and Ioannou and Serafeim (2012). The cultural dimension confirmed the negative influence of the greater concentration of power and greater individualism, as well as a negative influence of the country's higher orientation towards femininity on the disclosure of gender-related CSR information, whereas the findings of Grosser and Moon (2005) and Grosser (2009) point out the importance of women's characteristics for both CSR and its disclosure. Finally, the economic dimension of the NBS showed that the level of development positively influences disclosure, highlighting that the attainment of the country's economic objectives has repercussions on CSR and can contribute to gender equality.

\section{Conclusions}

The level of disclosure of CSR practices on gender by the studied companies was observed at an average of 7.41, considered low for signatory companies of the WEPs. Argentina, Colombia, Chile and Venezuela were the countries that presented the highest level of disclosure. It should be noted, however, that the latter has only one company that adhered to the WEPs. Panama and Mexico were the ones that presented the lowest level of disclosure. 
Of the 13 CSR indicators aimed at reducing gender inequality in companies aligned with the WEPs, the highest level of disclosure was composed of the highest governance body and its committees by gender (G4-38) and the groups responsible for governance and employee discrimination by functional category, according to gender (G4-LA12). The indicator of return to work and retention after maternity/paternity leave, broken down by gender (G4-LA3), was the least publicised.

Greater disclosure was found related to Principle 1, aimed at high-level corporate leadership for gender equality. Nevertheless, this does not indicate a female presence in the corporate governance bodies, but rather that the companies disclose their composition. Indeed, few companies studied had women in governance bodies.

The results obtained coincide with those of other studies consulted by British, Spanish, Finnish and Japanese companies, where the details of the information on gender is superficial. The results reinforce the need to investigate the influence of the NBS on the disclosure of information on gender-related CSR practices, aiming at advancing the resolution of issues related to the promotion of gender equity and strengthening the insertion and rise of women in companies.

In this sense, hypotheses about the influence of the NBS on the level of disclosure were not rejected: education and labour system - positive influence of union pressure; the country's cultural system-negative influence of the level of concentration of power, negative influence of the level of individualism; economic system - positive influence of the country's level of economic development.

The hypotheses refuted regarding the influence of the NBS on the level of disclosure were as follows: political system-positive influence of the country's enforcement power; financial system-positive influence of the financing of the country's companies through the capital market; cultural system-negative influence of the level orientation towards femininity.

The results are important to practitioners because they highlight the existing gaps in the quality of disclosure, because simply describing some practices is not enough and some measures such as quantitative absolute or relative numbers are necessary to evaluate the evolution of the practices adopted as well as the amplitude of them.

The results highlight the important role that some national and local institutions exert on women's empowerment, pressuring companies to report information on adopted practices such as unions, stock exchanges, securities and exchange commissions and this is relevant to the planning of a global agenda.

The study has limitations, such the observation over a period of only one year and the fact that the companies are WEP signatories, so the results obtained apply to the companies studied, but not to all companies in the countries studied. It is suggested that an investigation be held for a sequence of three years or more with a larger sample. Furthermore, some control variables (e.g., size, performance) whose effect on disclosure has been evidenced previously in the literature could be addressed in future research.

Author Contributions: All authors were equally involved in the research design, data collection and analysis, and paper writing. All authors read, edited, and approved the final manuscript.

Conflicts of Interest: The authors declare no conflict of interest.

\section{References}

Adams, Carol A., and George Harte. 1998. The changing portrayal of the employment of women in British banks' and retail companies' corporate annual reports. Accounting, Organizations and Society 23: 781-812. [CrossRef]

Aguilera, Ruth V., Deborah E. Rupp, Cynthia A. Williams, and Jyoti Ganapathi. 2007. Putting the S back in corporate social responsibility: A multilevel theory of social change in organizations. The Academy of Management Review 32: 836-63. [CrossRef]

Alon, Ilan, Christoph Lattemann, Marc Fetscherin, Shaomin Li, and Anna-Maria Schneider. 2010. Usage of public corporate communications of social responsibility in Brazil, Russia, India and China (BRIC). International Journal of Emerging Markets 5: 6-22. [CrossRef] 
Amran, Azlan, Shiau Ping Lee, and S. Susela Devi. 2014. The Influence of Governance Structure and Strategic Corporate Social Responsibility toward Sustainability Reporting Quality. Business Strategy Environment 23: 217-35. [CrossRef]

Baughn, C. Christopher, Nancy L. (Dusty) Bodie, and John C. McIntosh. 2007. Corporate Social and Environmental Responsibility in Asian Countries and Other Geographical Regions. Corporate Social Responsibility and Environmental Management 14: 189-205. [CrossRef]

Belal, Ataur Rahman. 2000. Environmental reporting in developing countries: Empirical evidence from Bangladesh. Eco-Management and Auditing 3: 114-21. [CrossRef]

Ben-Amar, Walid, Millicent Chang, and Philip Mcllkenny. 2017. Board Gender Diversity and Corporate Response to Sustainability Initiatives: Evidence from the Carbon Disclosure Project. Journal of Business Ethics 142: 369-83. [CrossRef]

Blindheim, Bjørn-Tore. 2015. Institutional models of corporate social responsibility: A proposed refinement of the explicit-implicit framework. Business $\mathcal{E}$ Society 54: 52-88.

Bonsón, Enrique, and Michaela Bednárová. 2015. CSR reporting practices of Eurozone companies. Spanish Accounting Review 18: 182-93. [CrossRef]

Braendle, Udo C. 2014. Recent developments in BRICS corporate governance with a focus on Russia-Innovation or imitation? Paper presented at The International Conference on Corporate Governance: A search for advanced standards in the wake of crisis, Milan, Italy, May 8; pp. 369-80.

Cahan, Steven F., Charl De Villiers, Debra Jeter, Naiker Vic, and Chris J. Van Staden. 2015. Are CSR Disclosures Value Relevant? Cross-Country Evidence. European Accounting Review 25: 579-611. [CrossRef]

Campbell, John L. 2007. Why would corporations behave in socially responsible ways? An institutional theory of corporate social responsibility. Academy of Management Review 32: 946-67. [CrossRef]

Celis, Izaskun Larrieta-Rubín de, Eva Velasco-Balmaseda, Sara Fernández de Bobadilla, María del Mar Alonso-Almeida, and Gurutze Intxaurburu-Clemente. 2015. Does having women managers lead to increased gender equality practices in corporate social responsibility? Business Ethics: A European Review 24: 91-110. [CrossRef]

Chen, Stephen, and Petra Bouvain. 2009. Is corporate responsibility converging? A comparison of corporate responsibility reporting in the USA, UK, Australia, and Germany. Journal of Business Ethics 87: 299-317. [CrossRef]

Deegan, Craig. 2002. The legitimising effect of social and environmental disclosures: A theoretical foundation. Accounting, Auditing \& Accountability Journal 15: 282-311.

Defond, Mark L., and Mingyi Hung. 2004. Investor Protection and Corporate Governance: Evidence from Worldwide CEO Turnover. Journal of Accounting Research 42: 269-312. [CrossRef]

Durnev, Art, Randall Morck, and Bernard Yeung. 2004. Value-Enhancing Capital Budgeting and Firm-Specific Stock Return Variation. Journal of Finance 59: 65-105. [CrossRef]

Fernandez-Feijoo, Belen, Silvia Romero, and Silvia Ruiz. 2012. Does Board Gender Composition affect Corporate Social Responsibility Reporting? International Journal of Business and Social Science 3: 31-38.

Fetscherin, Marc, Shaomin Li, Ilan Alon, Christoph Lattemann, and Kuang Yeh. 2010. Corporate social responsibility in emerging markets: The importance of the governance environment. Management International Review: Journal of International Business 50: 635-54.

Fuente, Juan Antonio, Isabel Maria García-Sanchez, and Maria Belén Lozano. 2017. The role of the board of directors in the adoption of GRI guidelines for the disclosure of CSR information. Journal of Cleaner Production 141: 737-50. [CrossRef]

García-Sánchez, Isabel-Maria, Beatriz Cuadrado-Ballesteros, and Jose-Valeriano Frias-Aceituno. 2016. Impact of the institutional macro context on the voluntary disclosure of CSR information. Long Range Planning 49: 15-35. [CrossRef]

Giannarakis, Grigoris, George Konteos, and Nikolaos Sariannidis. 2014. Financial, governance and environmental determinants of corporate social responsible disclosure. Management Decision 52: 1928-51. [CrossRef]

Gonçalves, Ednéia Batista do Prado, Márcia Maria dos Santos Bortolocci Espejo, Stella Maris Lima Altoé, and Simone Bernardes Voese. 2016. Gestão da diversidade: Um estudo de gênero e raça em brasileiras grandes empresas. Revista Enfoque Contábil 35: 95-111. [CrossRef]

Gray, Sidney J. 1988. Towards a theory of cultural influence on the development of accounting systems internationally. Abacus 24: 1-15. [CrossRef] 
Grosser, Kate. 2009. Corporate social responsibility and gender equality: Women as stakeholders and the European Union sustainability strategy. Journal of Business Ethics 18: 290-307. [CrossRef]

Grosser, Kate, and Jeremy Moon. 2005. Gender mainstreaming and corporate social responsibility: Reporting workplace issues. Journal of Business Ethics 62: 327-40. [CrossRef]

Grosser, Kate, and Jeremy Moon. 2008. Developments in company reporting on workplace gender equality: A corporate social responsibility perspective. Accounting Forum 32: 179-98. [CrossRef]

Helfaya, Akrum, and Tantawy Moussa. 2017. Do Board's Corporate Social Responsibility Strategy and Orientation Influence Environmental Sustainability Disclosure? UK Evidence. Business Strategy and the Environment 26: 1061-77. [CrossRef]

Heritage Foundation. 2016. Index of Economic Freedom: Promoting Economic Opportunity and Prosperity. Available online: http:/ / www.heritage.org/index/default (accessed on 13 July 2016).

Hofstede, Geert. 1983. The cultural relativity of organizational practices and theories. Journal of International Business Studies 14: 75-89. [CrossRef]

Hofstede, Geert H. 1997. Culturas e organizações: Compreender a nossa programação mental. Lisboa: Silabo.

Hofstede, Geert. 2016. Country Comparison. Available online: https:/ /www.hofstede-insights.com/product/ compare-countries / (accessed on 13 July 2016).

Hotho, Jasper J. 2014. From typology to taxonomy: A configurational analysis of national business systems and their explanatory power. Organization Studies 35: 671-702. [CrossRef]

Hyun, Eunjung, Daegyu Yang, Hojin Jung, and Kihoon Hong. 2016. Women on Boards and Corporate Social Responsibility. Sustainability 8: 300-26. [CrossRef]

International Financing Committee, Global Report Initiative. 2009. Embedding Gender in Sustainability Reporting: A Practitioner's Guide. Washington, DC: World Bank Group.

International Monetary Fund. 2016. World Economic Outlook Database October 2016. Available online: http:/ /www. imf.org/external/pubs/ft/weo/2016/02/weodata/weoselco.aspx?g=2001\&sg=All+countries (accessed on 13 October 2016).

Ioannou, Ioannis, and George Serafeim. 2012. What drives corporate social performance? The role of nation level institutions. Journal of International Business Studies 43: 834-64. [CrossRef]

Jensen, Julia Catharina, and Nicola Berg. 2012. Determinants of traditional sustainability reporting versus integrated reporting: An institutionalist approach. Business Strategy and the Environment 21: 299-316. [CrossRef]

Joseph, Corina, Juniati Gunawan, Yussri Sawani, Mariam Rahmat, Josephine Avelind Noyem, and Faizah Darus. 2016. A comparative study of anti-corruption practice disclosure among Malaysian and Indonesian Corporate Social Responsibility (CSR) best practice companies. Journal of Cleaner Production 112: 2896-906. [CrossRef]

Kassinis, George, Alexia Panayiotou, Andreas Dimou, and Georgia Katsifaraki. 2016. Gender and environmental sustainability: A longitudinal analysis. Corporate Social Responsibility and Environmental Management 23: 399-412. [CrossRef]

Kato, Takao, and Kodama Naomi. 2016. Corporate Social Responsibility and Gender Diversity in the Workplace: Evidence from Japan. RIETI Discussion Paper Series 16-E-063. Tokyo, Japan: Research Institute of Economy, Trade and Industry (RIETI).

Kirsch, Anja. 2017. The gender composition of corporate boards: A review and research agenda. The Leadership Quarterly 29: 346-64. [CrossRef]

Lattemann, Christoph, Marc Fetscherin, Ilan Alon, Shaomin Li, and Anna-Maria Schneider. 2009. CSR communication intensity in Chinese and Indian multinational companies. Corporate Governance: An International Review 17: 426-42. [CrossRef]

Liao, Lin, Le Luo, and Qingliang Tang. 2015. Gender diversity, board independence, environmental committee and greenhouse gas disclosure. The British Accounting Review 47: 409-24. [CrossRef]

Lopatta, Kerstin, Frerich Buchholz, and Thomas Kaspereit. 2016. Asymmetric information and corporate social responsibility. Business $\mathcal{E}$ Society 55: 458-88.

Mahadeo, Jyoti Devi, Vanisha Oogarah-Hanuman, and Teerooven Soobaroyen. 2011. Changes in social and environmental reporting practices in an emerging economy (2004-2007): Exploring the relevance of stakeholder and legitimacy theories. Accounting Forum 35: 158-75. [CrossRef] 
Matten, Dirk, and Jeremy Moon. 2008. "Implicit" and "explicit" CSR: A conceptual framework for a comparative understanding of corporate social responsibility. Academy of Management Review 33: 404-24. [CrossRef]

Neumayer, Eric, and Richard Perkins. 2004. What explains the uneven take-up of ISO 14001 at the global level? A panel-data analysis. Environment and Planning 36: 823-39. [CrossRef]

Ringov, Dimo, and Maurizio Zollo. 2007. The impact of national culture on corporate social performance. Corporate Governance 7: 476-85. [CrossRef]

Rodríguez-Domínguez, Isabel, Isabel María García-Sánchez, and Luis Rodríguez-Dominguez. 2010. The influence of gender diversity on corporate performance. Revista de Contabilidad 13: 56-88.

Scholtens, Bert, and Lammertjan Dam. 2007. Cultural values and international differences in business ethics. Journal of Business Ethics 75: 273-84. [CrossRef]

Setó-Pamies, Dolors. 2015. The Relationship between Women Directors and Corporate Social Responsibility. Corporate Social Responsibility and Environmental Management 22: 334-45. [CrossRef]

The World Bank. 2016. World Development Indicators. Available online: http:/ / databank.worldbank.org/data/ reports.aspx?source=2\&series=NY.GDP.MKTP.CD\&country=\# (accessed on 4 October 2016).

Thompson, Lindsay J. 2008. Gender equity and corporate social responsibility in a post-feminist era. Business Ethics: A European Review 17: 87-106. [CrossRef]

Transparency International. 2015. Corruption Perceptions Index 2015. Available online: http:/ / files.transparency. org/content/download/1956/12836/file/2015_CPI_data.xlsx (accessed on 4 October 2016).

Turban, Daniel B., and Daniel W. Greening. 1997. Corporate social performance and organizational attractiveness to prospective employees. Academy of Management Journal 40: 658-72. [CrossRef]

Turban, Daniel B., and Daniel W. Greening. 2000. Corporate social performance as a competitive advantage in attracting a quality workforce. Business $\mathcal{E}$ Society 39: 254-80.

United Nations (UN) Women, and United Nations (UN) Global Compact. 2014. Women's Empowerment Principles: Reporting on Progress. Equality Means Business. Guidance Document; Available online: http:/ /weprinciples. org/files/attachments/WEPs_Reporting_Guidance_G4_Sept2014pdf.pdf (accessed on 13 July 2016).

Verrecchia, Robert E. 2001. Essays on disclosure. Journal of Accounting and Economics 32: 97-180. [CrossRef]

Vuontisjarvi, Taru. 2006. Corporate social reporting in the European context and human resource disclosures: An analysis of Finnish companies. Journal of Business Ethics 69: 331-54. [CrossRef]

Wang, Qian, Junsheng Dou, and Shenghua Jia. 2016. A meta-analytic review of corporate social responsibility and corporate financial performance: The moderating effect of contextual factors. Business $\mathcal{E}$ Society 55: 1083-121.

Whitley, Richard. 1999. Divergent Capitalisms: The Social Structuring and Change of Business Systems. Oxford: Oxford University Press.

Whitley, Richard. 2003. How national are business systems? The role of different state types and complementary institutions in constructing homogenous systems of economic coordination and control. Paper presented at Workshop on National Business Systems in the New Global Context, Oslo, Norway, May 8-11.

Wooldridge, Jeffrey M. 2012. Introdução à Econometria: Uma Abordagem Moderna, 2nd ed. São Paulo: Cengage Learning.

World Economic Forum. 2016. The Global Competitiveness Report 2016-2017. Available online: http:/ / www3.weforum.org/docs/GCR2016--2017/05FullReport/TheGlobalCompetitivenessReport20162017_FINAL.pdf (accessed on 13 October 2016).

Yin, Juelin. 2017. Institutional drivers for corporate social responsibility in an emerging economy: A mixed-method study of Chinese business executives. Business \& Society 56: 672-704.

(C) 2018 by the authors. Licensee MDPI, Basel, Switzerland. This article is an open access article distributed under the terms and conditions of the Creative Commons Attribution (CC BY) license (http://creativecommons.org/licenses/by/4.0/). 